\title{
Perception Analysis of Employees on The Implementation of Bureaucratic Reforms in Government Procurement Of Policy Institutions
}

\author{
Hestri Rokayah \\ Politeknik STIA LAN Jakarta, Indonesia
}

\{1964002018@stialan.ac.id\}

\begin{abstract}
LKPP has implemented Bureaucratic Reform and has received an assessment from the Ministry of Administrative Reform and Bureaucratic Reform (KemenPAN-RB). Identification of problems that arise from the implementation of Bureaucratic Reform in LKPP including the increase in the value of Bureaucratic Reform from year to year which has an insignificant increase, perceptions/understanding of the various definitions and scopes of Bureaucratic Reform, the implementation of Bureaucratic Reform seems to focus more on document fulfillment. as a result of the implementation of activities in each of the Bureaucratic Reform Teams that have been formed. This study aims in particular to analyze employee perceptions of the implementation of Bureaucratic Reform in LKPP. The method used is a qualitative research method with a descriptive approach. Data was collected through interviews, observation, and document review/analysis. The research informants were 14 people consisting of: 3 representatives of the LKPP Bureaucratic Reform Team members, 1 person from the head of the sub-section, 6 certain functional positions as sub-coordinators, and 2 certain functional positions and 2 general functional positions/PNS staff. The results showed that there were differences in the perception of LKPP employees towards the implementation of Bureaucratic Reform in LKPP, the difference in perception was due to differences in obtaining information, differences in providing understanding, and differences in and providing an assessment of the implementation of Bureaucratic Reform in LKPP, especially regarding the insignificant value of Bureaucratic Reform. There are findings on the implementation of Bureaucratic Reform in LKPP based on research results, namely: they have carried out activities as well as possible to improve Bureaucratic Reform in LKPP, provided the best possible service to the community, responded quickly to changes and directions from the government, lack of documentation in carrying out activities, lack of socialization and internalization related to the implementation of Bureaucratic Reform. Based on these findings, in order to improve, strategies that can be carried out include socializing and internalizing Bureaucratic Reform for the eight areas of change, continuing to evaluate the values of bureaucratic reform that have been obtained, creating innovations for improvement. Bureaucratic Reform, as well as the involvement of all parties, both from the leaders and from the implementing staff in implementing Bureaucratic Reform in LKPP.
\end{abstract}

Keywords: reform; bureaucracy; bureaucratic reform; perception

\section{Introduction}

Organizations are faced with challenges in managing changes in community behavior, competitor movements, and various other aspects. Indirectly, this encourages organizations to make adjustments effectively and efficiently, including related to governance in 
Ministries/Agencies/Local Governments (K/L/PD). An effective government regulatory system will create a regulatory system for work in $\mathrm{K} / \mathrm{L} / \mathrm{PD}$ to be more structured so that it can achieve the vision, mission, and goals of each agency.

As stated in Presidential Regulation Number 81 of 2010 concerning the Grand Design of Bureaucratic Reform in 2010-2025. The Presidential Regulation was drafted in order to accelerate the achievement of an effective system of government regulation in all $\mathrm{K} / \mathrm{L} / \mathrm{PD}$. The Grand Design for Bureaucratic Reform is a master design that contains the policy directions for the implementation of national Bureaucratic Reform for 2010-2025. While the Bureaucratic Reform Road Map is a detailed derivative of the Grand Design of Bureaucratic Reform which is compiled and carried out every 5 (five) years and is a detailed plan for Bureaucratic Reform from one stage to the next for 5 (five) years with clear and measurable targets for each year.

The implementation of the derivative of the Grand Design of Bureaucratic Reform in 2010 - 2025 will be lowered into the Road Map of Bureaucratic Reform and become material for $\mathrm{K} / \mathrm{L} / \mathrm{PD}$ in order to realize effective governance to achieve the vision, mission, and goals of the $\mathrm{K} / \mathrm{L} / \mathrm{PD}$. Bureaucracy in Indonesia which consists of Ministries, Non-Ministerial Government Institutions, and Local Governments each year gets an assessment of Bureaucratic Reform in their agencies carried out by the Ministry of Empowerment of State Apparatus and Bureaucratic Reform. The government through the Ministry of Empowerment of State Apparatus and Bureaucratic Reform (KemenPAN-RB) periodically evaluates Bureaucratic Reform in all $\mathrm{K} / \mathrm{L} / \mathrm{PD}$, in order to obtain data and information on the progress of the implementation of Bureaucratic Reform in each K/L/PD.

Bureaucratic Reform of a K/L/PD is one of the indicators in assessing the management of governance that is being carried out by the agency. The Government Goods/Services Procurement Policy Institute (LKPP) is one of the Non-Ministerial Government Institutions and is part of a larger bureaucratic system. LKPP has an obligation to follow the Bureaucratic Reform process which is currently one of the important activities of the Government that must be implemented. Bureaucratic reform in LKPP is always carried out because it is a process to rearrange, change, improve and perfect the LKPP bureaucracy to be better, namely, to become more professional, efficient, effective and productive.

The implementation of Bureaucratic Reform in LKPP is an important agenda that is always carried out, this is because the role and function of LKPP in formulating policies in the field of Government Procurement of Goods/Services (PBJP) is closely related to the reform process itself, especially reforms in the governance of government spending/state finances. In this case, LKPP has a role to play in encouraging increased efficiency and effectiveness of government spending so that quality public goods/services are obtained and in accordance with predetermined standard requirements.

The following are the results of LKPP Bureaucratic Reform from the Ministry of Administrative Reform and Bureaucratic Reform (KemenPAN-RB) in 2016 to 2019.

Table 1. Assessment of LKPP Bureaucratic Reform in 2016-2019

\begin{tabular}{|c|c|c|c|c|c|c|}
\hline \multirow{2}{*}{ No } & \multirow{2}{*}{ Assessment Component } & \multirow{2}{*}{ Weight } & \multicolumn{4}{|c|}{ Year } \\
\hline I & Leverage Component & & & & & \\
\hline 1 & Change management & 5,00 & 3,12 & 3,80 & 4,29 & 4,31 \\
\hline 2 & Structuring Legislation/Policy Deregulation & 5,00 & 4,38 & 4,38 & 4,38 & 4,38 \\
\hline
\end{tabular}




\begin{tabular}{|c|c|c|c|c|c|c|}
\hline 3 & Organizational Structuring and Strengthening & 6,00 & 4,01 & 4,83 & 4,84 & 4,84 \\
\hline 4 & Management Arrangement & 5,00 & 3,80 & 3,93 & 4,20 & 4,29 \\
\hline 5 & HR Management System Setup & 15,00 & 12,51 & 13,18 & 13,33 & 13,37 \\
\hline 6 & Strengthening Accountability & 6,00 & 2,88 & 2,72 & 2,85 & 3,32 \\
\hline 7 & Supervision Strengthening & 12,00 & 6,40 & 6,40 & 6,35 & 6,85 \\
\hline \multirow[t]{2}{*}{8} & Improving the Quality of Public Services & 6,00 & 3,89 & 4,06 & 4,89 & 5,08 \\
\hline & Total Leverage Components (A) & 60,00 & 40,99 & 43,30 & 45.13 & 46,44 \\
\hline II & Yield Component & & & & & \\
\hline 1 & Performance Accountability Value & 14,00 & 8,52 & 8,99 & 8,67 & 8,74 \\
\hline 2 & Organizational Capacity Value & 6,00 & 5,72 & 4,64 & 4,04 & 4,58 \\
\hline 3 & Corruption Perception Value & 7,00 & 6,09 & 6,02 & 6,00 & 5,55 \\
\hline 4 & CPC opinion & 3,00 & 3,00 & 2,00 & 3,00 & 3,00 \\
\hline \multirow[t]{3}{*}{5} & Service Quality Perceived Value & 10,00 & 8,08 & 8,45 & 8,18 & 6,78 \\
\hline & Total Result Component (B) & 40,00 & 31,41 & 30,10 & 29,89 & 28,65 \\
\hline & Bureaucratic Reform Index $(A+B)$ & 100,00 & 72,40 & 73,40 & 75,02 & 75,09 \\
\hline
\end{tabular}

Table 1.1 shows the problems that arise very clearly that the increase in the value of Bureaucratic Reform in LKPP in 2016 - 2019 there is an increase in the value of RB which fluctuates with an average increase of only 0.897 points, where this value is considered not optimal. The implementation of Bureaucratic Reform is still considered as an additional task and has not become an integrated part of the strategy to improve efficiency and effectiveness in the implementation of daily tasks in realizing agency performance. In general, the work units have not implemented the arrangement of the eight areas of Bureaucratic Reform changes that have resulted in real changes. This has resulted in the ultimate goal of implementing Bureaucratic Reform, namely changes in mindset and work culture at all levels.

The above situations and conditions can be caused because employees do not/have not realized what is actually expected from the tasks and work they do relate to the implementation of Bureaucratic Reform. The presence of employees seems to focus more on completing their routine work tasks, so that it can result in the absence of a significant increase in performance 
substance. This opinion is in line with several previous studies, among others, conducted by Phillip G. Clampit \& Cal W. Downs, Robert Johnston \& Janelle Heineke, who in their research found a positive relationship between employee perceptions and productivity or performance.

Based on the description above, it is necessary to have study materials in an effort to make improvements, innovations, or breakthroughs that must be carried out in the implementation of Bureaucratic Reform in LKPP. One of the efforts to get innovations or breakthroughs that must be carried out by LKPP is one of them by identifying or asking employees for views/perceptions on the implementation of Bureaucratic Reform.

From the information above, it is necessary to study the perceptions of LKPP employees to find out the extent to which LKPP employees understand the implementation of Bureaucratic Reform in LKPP. Departing from the problems mentioned above, the research that will be taken by the researcher is entitled "Analysis of Employee Perceptions on the Implementation of Bureaucratic Reform in LKPP."

\section{Literature Review}

According to Asmawi (2012: 161) Grand Design Bureaucratic Reform has a very important meaning, because:

a. Become an instrument that connects the direction of the Bureaucratic Reform policy as stated in the 2005-2025 Short Term Development Plan (RPJP) with its operational steps, especially for the Medium-Term Development Plan (RPJM) period;

b. To become the basic framework in developing detailed steps (road map) of Bureaucratic Reform during the five-year period nationally.

c. Become the basic framework for $\mathrm{K} / \mathrm{L} / \mathrm{PD}$ in compiling a road map for Bureaucratic Reform in their agencies.

Based on the Regulation of the Minister of Administrative Reform and Bureaucratic Reform Number 25 of 2020 concerning the Road Map of Bureaucratic Reform 2020-2024, there are eight areas of change in Bureaucratic Reform that are the focus of development, including the following:

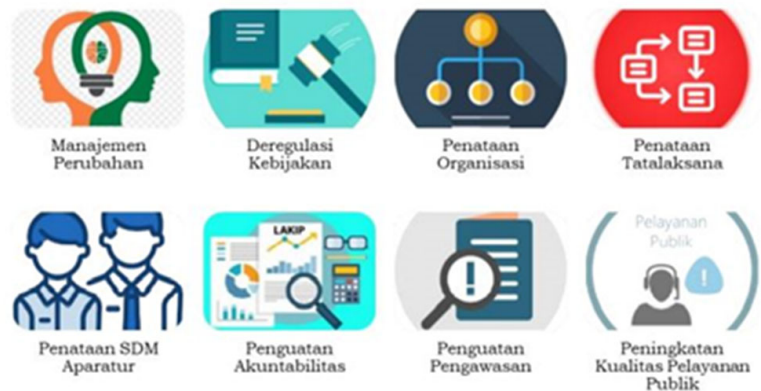

Fig 1. Area of Change for the Bureau of Crate Reform (Source: PermenPAN-RB Number 25 of 2021 concerning Road Map Bureaucratic Reform 2020-2024)

\section{Perception}

According to Webster (in Hariisah and Masiming, 2008:30) perception has the following meanings:

a. The activity of feeling or the ability to feel, understand the soul of objects, qualities and others through the meaning of taste, awareness, comparison. 
b. Deep knowledge, intuition or the ability of the five senses to understand something.

c. Understanding, knowledge and others received by way of feeling, or special ideas, concepts, impressions and others that are formed.

According to Bimo, Walgito (2002: 99), perception has the following aspects:

a. Absorption of information on stimuli or objects from outside the individual.

The stimulus or object is absorbed or received by the five senses, both sight, hearing, touch, smell, and taste alone or together. The stimulus or object is interpreted in the form of information which can be in the form of responses, data, impressions so that they are collected into images and make them a perception.

b. Understanding or understanding

After the information is obtained, it is continued by doing groupings, making comparisons, interpreted into an understanding or understanding which of course is also determined from experience, background, and environmental conditions.

c. Assessment or evaluation

The understanding or understanding that has been obtained will develop into an assessment or evaluation that is compared to the applicable rules, regulations, or norms. The perception of one person will be different from the perception of others, because the perception is individual.

The most important thing in the implementation of this research / the key concept is the employee's perception of the implementation of Bureaucratic Reform in LKPP. What is meant by perception is an activity to be able to absorb the information obtained, followed by understanding and processing information into knowledge, and drawing conclusions from that understanding, in this case, namely the implementation of Bureaucratic Reform in LKPP. This is built from Webster's theory in Harisah and Masiming (2008:30). The aspects of perception consist of absorption of information, understanding derived from the information obtained, and evaluation in terms of drawing conclusions (built from the theory of Bimo Walgito, 2010: 99).

\section{Research Methods}

The research was conducted using qualitative research methods. Bungin, Burhan (2015: 27) states that the research method is a way to obtain data based on the research to be studied." Burhan Bungin further stated that research is a structured activity to obtain responses to questions from researchers to take solutions to problems that arise.

The qualitative research method with a descriptive approach was chosen with the following considerations:

a. The use of qualitative methods is more in-depth and is used to dig up information based on facts that occur in the field;

b. This method can see the results of research from various points of view because it has an impact on the effect of research on the data obtained.

c. Provide more accurate research results because it directly obtains information from respondents/research informants who are directly involved in the activities.

Data collection techniques used are: interviews, observation, and document review. Interviews were conducted in a planned and structured manner so that in conducting interviews using interview guidelines to be carried out properly and regularly. In the research conducted, 
the researcher uses participant observer/participatory observation, because the researcher is directly involved in observing the activities being researched related to the implementation of Bureaucratic Reform in LKPP. In this study, the observation method that will be used is to observe eight areas of change made by LKPP.

Document review is carried out by taking data and information based on several sources such as books, research results, journals, websites, and other sources that are related to perceptions of the implementation of Bureaucratic Reform in Ministries/Institutions/Local Governments. Meanwhile, for the study of documents in LKPP itself, researchers took data from the Bureaucratic Reform assessment report, LKPP annual performance report, Presidential Regulation on Performance Allowances, recapitulation of attendance of Government Goods/Services Procurement Agency employees, as well as other documents related to Bureaucratic Reform.

After having the data, the next step is to analyze the data. Analysis of the data used is the Miles and Huberman model. Miles and Huberman (in Yusuf, Muri, 2019: 407) assert that in research conducted using qualitative methods, the data obtained can come from various sources with various data collection techniques such as from interviews, interviews, observations, quotations, important topics from a note or discussion meeting, and obtained from data that can be in the form of numbers or symbols or tables. Miles and Huberman (in Yusuf, Muri, 2019: 407), suggest the steps in data analysis, namely: Data Reduction, Data Display, and Conclusions.

\section{Results}

This research was conducted from March 31, 2021 to April 27, 2021 at the Government Goods/Services Procurement Policy Institute (LKPP). The research was conducted through interviews, observation, and document review. Interviews were conducted with 14 key informants. The results of the study were analyzed by researchers using qualitative methods with a descriptive approach, which was carried out by means of researchers describing, describing, and interpreting all collected data so that they were able to obtain a general and comprehensive picture related to employee perceptions of the implementation of Bureaucratic Reform in LKPP.

Based on the results of the analysis of research conducted on informants on the implementation of Bureaucratic Reform and in eight areas of change, there are findings that the implementation of Bureaucratic Reform in LKPP, including:

a. Generally related to management:

- The PIC or Bureaucratic Reform Team sometimes does not focus on work related to Bureaucratic Reform, because they also carry out main tasks in their technical work units as well as technical work units at LKPP are too busy in carrying out their respective main tasks.

- Lack of requirements or documentation of activities required at the time of the Bureaucratic Reform assessment carried out by KemenPAN RB.

- It is not optimal to conduct a study on the value of Bureaucratic Reform and has not been used as a strategic issue.

- Lack of awareness, internalization of individual employees related to Bureaucratic Reform. 
- Lack of socialization/publication related to Bureaucratic Reform, so that there is a discrepancy in the notions or definitions related to Bureaucratic Reform.

- $\quad$ Limited budget in LKPP.

- There is no application or IT system that integrates all documents related to Bureaucratic Reform activities at LKPP

b. Change Management Area

- The synchronization of the action plan for Bureaucratic Reform is not optimal yet from one work unit to other work units in LKPP.

- The LKPP Internal Assessor Team has just been formed, but there is no Internal Quality Management Team at LKPP for the activities of implementing Bureaucratic Reform.

- The term or nomenclature of change management for employees in LKPP has not yet been socialized.

c. Areas of Policy Deregulation

- There is no established regulatory tree to map which regulations/regulations need to be integrated, removed, or which regulations or regulations overlap.

- There is no code of ethics for contract employees who are recruited as other services, the existing code of ethics only applies to Civil Servants (PNS) and to Prospective Civil Servants (CPNS).

d. Organizational Arrangement Area

- There is still no formation of certain functional positions that are in accordance with their duties and functions even though the organization has been simplified by making certain functional position equalization for echelon 3 and echelon 4 .

- Not all echelon 1 has its own secretarial division, the secretariat still relies on the Program and Finance Division.

e. Management Arrangement Area

- The SOPs between work units in LKPP have not been integrated, so that each work unit prepares SOPs that are independent and too detailed which can actually be integrated.

- There are still SOPs that have not been approved/defined.

f. Apparatus Human Resources Arrangement Area

- $\quad$ Limited budget to facilitate competency development such as training for individual civil servants or CPNS at LKPP.

- $\quad$ There is no regulation on the merit system to increase competence for employees.

g. Areas of Strengthening Accountability

- Documentation of work results is not well documented.

- Innovations are needed to strengthen the implementation of accountability in LKPP, such as the existence of an application or IT system that can show the results of the work of each work unit that can be accessed by all work units in LKPP.

h. Supervision Strengthening Area

Innovations are needed in strengthening the implementation of supervision in LKPP, such as the existence of an application or IT system that can show the results of internal supervision of each work unit that can be accessed by all work units in LKPP.

i. Area of Public Service Quality Improvement

- Innovations are needed in strengthening the implementation of public services at LKPP, such as the existence of an application or IT system that can be accessed by all work units in LKPP and can be accessed by all stakeholders. 
- There is no socialization of service standards or service announcements from each work unit in LKPP to all employees.

Based on the findings of the research, a strategy or method is needed to improve the implementation of Bureaucratic Reform. Differences in perception between individuals caused by differences in information absorption, understanding, or assessment can be corrected by improving perceptions about Bureaucratic Reform. This is supported by the theory put forward by Mc Shane and Von Glinow (in Simbolon, 2008: 61), that: "To correct errors or distortions in perception, there are strategies, namely: diversity management programs (increasing knowledge or skills for employees with the aim that employees can carry out their duties in their work clearly), empathize with others (increase a person's ability to understand their environment, understand situations that require occurring in the environment), postpone impression formation (related to strategies to collect reliable data, compare perceptions with others (related to how to provide feedback/suggestions or input so that improvements can be made.)"

Referring to this theory, in order to improve the implementation of Bureaucratic Reform in LKPP, strategies that can be carried out are needed, including:

a. Generally related to management:

- It takes commitment and active involvement from all parties in implementing Bureaucratic Reform in LKPP from the leadership to the implementing staff.

- There is a need for socialization and internalization related to Bureaucratic Reform to all employees.

- Re-evaluate the value of Bureaucratic Reform that has been obtained to make improvements, especially in the eight areas of change.

- It is necessary to have a common perception regarding the definition, scope, and procedures for evaluating Bureaucratic Reform between LKPP and KemenPAN RB as assessors of Bureaucratic Reform.

- Document documentation is required for every activity carried out that can be integrated into an application or system

- It is necessary to have innovations that can continue to be carried out in order to improve the implementation of Bureaucratic Reform in LKPP, including: creating information technology applications or application systems that are integrated in all work units in LKPP and can be accessed by all work units in LKPP.

b. Change Management Area

- The existence of the LKPP Internal Quality Management Team in implementing Bureaucratic Reform at LKPP with the aim of the team being tasked with ensuring that all parts/all areas of change contained in the implementation of Bureaucratic Reform are in accordance with the processes and requirements determined by the KemenPANRB.

- There is synchronization of action plans for Bureaucratic Reform from each work unit in LKPP, with discussion meetings to explain the action plans of each work unit and classify action plans that can be integrated

- The existence of a Bureaucratic Reform application system which contains an action plan for each unit that can be seen and accessed by all work units in LKPP.

c. Areas of Policy Deregulation

- Compilation of a regulatory tree with a formula for compiling a regulatory tree and setting it as a guide or guideline that can be used by each work unit, so that it can be 
used to map which regulations/regulations need to be integrated, eliminated, or which regulations or regulations overlap.

- Compilation of a code of ethics that applies to all employees at LKPP, whether for civil servants, civil servants, or employees who work under contracts/other services.

d. Organizational Arrangement Area

- A re-evaluation of the position equalization formation has been carried out.

- Planning for each Echelon 1 has a secretariat, so that each Echelon 1 work unit has a place or facility to carry out administrative tasks so that the documentation of activities is more organized.

e. Management Arrangement Area

- There is an integration of SOPs in work units at LKPP for activities or jobs with the same characteristics, so that they can be used together.

- There are SOPs that have been prepared and have been validated.

- There is socialization of SOPs in LKPP to all employees.

f. Apparatus Human Resources Arrangement Area

- The merit system is implemented for employees so that it can be ensured that a certain position is occupied by employees who meet the qualifications and competencies required in a position.

- There is a need analysis for competency development for each employee, so that each employee has a competency development tree that must be carried out and can see what training priorities are needed, so that with the limited budget they can still meet the needs of each employee to improve their competence.

g. Areas of Strengthening Accountability

The existence of an application or IT system that can show the results of the work of each work unit that can be accessed by all work units in LKPP.

h. Supervision Strengthening Area

There are innovations in strengthening the implementation of supervision at LKPP, such as the application or IT system that can show the results of internal supervision of each work unit that can be accessed by all work units in LKPP.

i. Area of Public Service Quality Improvement

- There are innovations in strengthening the implementation of public services in LKPP, such as the existence of an application or IT system that can be accessed by all work units in LKPP and can be accessed by all stakeholders.

- There is socialization of service standards or service announcements from each work unit in LKPP to all employees, so that if stakeholders need information or facilitation from LKPP, all employees are aware of the services that must be provided to each stakeholder.

\section{Conclusion}

After conducting research on employee perceptions of the implementation of Bureaucratic Reform in LKPP, the conclusions in this study are as follows:

a. There are differences in the absorption of information on Bureaucratic Reform conveyed by key informants. This is due to differences in obtaining information about Bureaucratic Reform. 
b. There are differences in the understanding of Bureaucratic Reform information conveyed by key informants for the eight areas of change, namely starting from the change management area, policy deregulation, organizational restructuring, management arrangement, apparatus Human Resources (HR) arrangement, strengthening accountability, strengthening supervision, to improving the quality of public services. This difference in understanding is due to differences in the absorption of information, experience, background, and other stimuli, causing interpretations that result in different understandings of each informant.

c. There are differences in the assessment of Bureaucratic Reform submitted by key informants. The Government Goods/Services Procurement Policy Institute (LKPP) has carried out activities related to Bureaucratic Reform for the eight areas of change, starting from the change management area, policy deregulation, organizational arrangement, management arrangement, Human Resources (HR) arrangement. apparatus, strengthening accountability, strengthening supervision, to improving the quality of public services. Continuous improvements have been made in implementing the eight areas of Bureaucratic Reform change, but it is still necessary to have strategies that can be done to improve the implementation of Bureaucratic Reform in LKPP.

\section{Suggestion}

a. To equalize information on Bureaucratic Reform, which is different for each employee, socialization regarding Bureaucratic Reform should be carried out for all levels of employees, so that it will raise awareness and involvement of all parties in LKPP in an effort to carry out activities within the framework of Bureaucratic Reform.

b. To improve the ability to understand Bureaucratic Reform, it is necessary to make continuous improvements in implementing the eight areas of change, breakthroughs/innovations, socialization, internalization in order to improve the value of Bureaucratic Reform in LKPP so as to create self-awareness for every employee to continue learning and learn about Bureaucratic Reform so that understanding is in accordance with the definition or scope of Bureaucratic Reform itself and its eight areas of change.

c. To improve the assessment of Bureaucratic Reform in LKPP, it is better to implement Bureaucratic Reform strategies in LKPP, including:

In general, related to management should be done:

- There is commitment and active involvement of all parties in implementing Bureaucratic Reform in LKPP from the leadership to the implementing staff.

- There is socialization and internalization related to Bureaucratic Reform to all employees.

- Re-evaluating the value of Bureaucratic Reform that has been obtained to make improvements, especially in the eight areas of change.

- It is necessary to have a common perception regarding the definition, scope, and procedures for evaluating Bureaucratic Reform between LKPP and KemenPAN RB as assessors of Bureaucratic Reform.

- Documentation is required for every activity carried out that can be integrated into an application or system

- It is necessary to have innovations that can continue to be carried out in order to improve the implementation of Bureaucratic Reform in LKPP, including: creating 
information technology applications or application systems that are integrated in all work units in LKPP and can be accessed by all work units in LKPP.

Change Management Area, should be done:

- The existence of an LKPP Internal Quality Management Team in implementing Bureaucratic Reform in LKPP with the aim of the team being tasked with ensuring that all parts/all areas of change contained in the implementation of Bureaucratic Reform are in accordance with the processes and requirements determined by the KemenPANRB.

- There is a synchronization of the action plans for Bureaucratic Reform from each work unit in LKPP, with a discussion meeting to explain the action plans of each work unit and classify the action plans that can be integrated

- The existence of a Bureaucratic Reform application system which contains an action plan for each unit that can be seen and accessed by all work units in LKPP

Areas of Policy Deregulation, should be done:

- Compilation of a regulatory tree accompanied by a formula for compiling a regulatory tree and setting it as a guide or guideline that can be used by each work unit, so that it can be used to map which regulations/regulations need to be integrated, eliminated, or which regulations or regulations need to be overlap.

- Compilation of a code of ethics that applies to all employees at LKPP, whether for civil servants, civil servants, or employees who work under contracts/other services.

Organizational Arrangement Area, should be done:

- A reevaluation of the position equalization formation has been carried out.

- Planning for each Echelon 1 to have a secretariat, so that each Echelon 1 work unit has a place or facility to carry out administrative tasks so that the documentation of activities is more organized.

Management Arrangement Area, should be done:

- There is an integration of SOPs in work units at LKPP for activities or jobs with the same characteristics, so that they can be used together.

- There are SOPs that have been prepared and have been validated.

- There is socialization of existing SOPs in LKPP to all employees.

Area of Apparatus Human Resources Management, should be carried out:

- The implementation of a merit system for employees so that it can be ensured that a certain position is occupied by an employee who meets the qualifications and competencies required in a position.

- $\quad$ There is a need analysis for competency development of each employee, so that each employee has a competency development tree that must be carried out and can see what training priorities are needed, so that with the limited budget they can still meet the needs of each employee to improve their competence.

Areas of Strengthening Accountability

- The existence of an application or IT system that can show the results of the work of each work unit that can be accessed by all work units in LKPP, such as the creation of 
the LKPP e-LAKIP application system, which is an electronic system that integrate all performance accountability reports in all work units in LKPP.

Supervision Strengthening Area

- There are innovations in strengthening the implementation of supervision at LKPP, such as the existence of an application or IT system that can show the results of internal supervision of each work unit that can be accessed by all work units in LKPP, such as the creation of the LKPP SIMWA (Supervision System) application system, an eplication system that integrates internal control that has been carried out by each work unit in LKPP.

Public Service Quality Improvement Area

- There are innovations in strengthening the implementation of public services at LKPP, such as the existence of an application or IT system that can be accessed by all work units in LKPP and can be accessed by all stakeholders, such as the creation of the PTSP LKPP, e-Portal application which contains all information and service facilitation. public in LKPP

- There is socialization of service standards or service announcements from each work unit in LKPP to all employees, so that if stakeholders need information or facilitation from LKPP, all employees are aware of the services that must be provided to each stakeholder.

\section{References}

[1] Anggraeni, Diah. 2016. Bureaucratic Reform In The Empirical Perspective And Pathology. Jurnal Institut Pemerintahan Dalam Negeri (IPDN).

[2] Angkasah Lalu, Adolf Huala, dan Asikin Zainal. 2017. Bureaucratic Reform in the

[3] Perspective of State Administration Law. Mediterranen Journal of Social Sciences. Vol. 8, No.5.

[4] Arikunto. 1996. Prosedur Penelitian Suatu Pendekatan Praktek (Edisi Revisi III). Yogyakarta: PT. Rineka Cipta.

[5] Bungin, Burhan. 2005. Metodologi Penelitian Kuantitatif Komunikasi, Ekonomi, dan Kebijakan Publik Ilmu-Ilmu Sosial Lainnya. Jakarta: Kencana.

[6] Chandra, Leo Addy. 2013. Pengaruh Budaya Organisasi Terhadap Kinerja Pegawai Kantor Ketahanan Pangan dan Penyuluhan Kabupaten Kutai Barat. Jurnal Administrasi Negara, I(3) 2013: 885-889.

[7] Clampitt, Philip G dan Downs, Cal W. 1993. Employee Perceptions of the Relationship Between Communication and Productivity: A Field Study. The Journal of Business Communication. Vol 30, No.01.

[8] Fahturrahman. 2016. Faktor Birokrasi dalam Keberhasilan Implementasi Kebijakan Publik. Jurnal Tarbawi. Vo..2, No.02.

[9] Harisah, Afifah dan Masiming Zulfitria. 2008. Persepsi Manusia terhadap Tanda, Simbol, dan Spasial. Jurnal SMARTek. Vol.6, No.1.

[10] Hoag, Colin. 2011. Assembling Partial Perspectives: Thoughts on the Anthropology of Bureaucracy. Jurnal University of California, Santa Cruz.

[11] Hood, Christopher dan Lodge Martin. 2004. Competency, Bureaucracy and Public Management Reform: A Comparative Analysis. An International Journal of Policy, Administration, and Institutions, Oxford. Vol. 17, No. 3.

[12] Ikhwan, Afiful. 2017. Kajian Sosio Historis Pendidikan Islam Indonesia Era Reformasi. Vol.05, No.01.

[13] Johnston, Robert dan Heineke, Janelle. 1998. Exploring the Relationship between Perception and Performance: Priorities for Action. The Service Industries Journal, USA. Vol. 18. No. 1 
[14] Kong, Eric dan Prior Daniel. 2007. An Intellectual Capital Perspective of Competitive Advantage in Nonprofit Organisations. International Journal of Nonprofit and Voluntary Sector Marketing Int. J. Nonprofit Volunt. Sect. Mark, Australia. 13: 119-128.

[15] Muhamad. 2008. Metode Penelitian Ekonomi Islam Pendekatan Kuantitatif. Jakarta: PT Raja Grafindo Persada.

[16] Moelong. 2002. Metodologi PenelitianKualitatif. Bandung: PT. Remaja Rosdakarya.

[17] Moynihan, Donald P. 2016. Normative and Instrumental Perspective On Public Participation. Jurnal Texas A and M University.

[18] Peraturan Presiden Nomor 81 Tahun 2010 tentang Grand Design Reformasi Birokrasi 2010-2025.

[19] Peraturan Menteri Pendayagunaan Aparatur Negara dan Reformasi Birokrasi Nomor 11 Tahun 2015 tentang Road Map Reformasi Birokrasi 2015 - 2019.

[20] Peraturan Menteri Pendayagunaan Aparatur Negara dan Reformasi Birokrasi Nomor 25 Tahun 2020 tentang Road Map Reformasi Birokrasi 2020-2024.

[21] Rewansyah, Asmawi. 2012. Kepemimpinan dam Pelayanan Publik. Jakarta: PT. Rizky Grafis.

[22] Rewansyah, Asmawi. 2012. Reformasi Birokrasi dalam Rangka Good Governance. Jakarta: PT. Rizky Grafis.

[23] Romli, Lili. 2008. Masalah Reformasi Birokrasi. Jurnal Kebijakan dan Manajemen PNS. Vol.2, No.2.

[24] Simbolon, Maropen. 2008. Persepsi dan Kepribadian. Jurnal Ekonomi dan Bisnis. Vol.2, No.1.

[25] Sulaeman, Budiman. 2013. Reformasi Pemikiran Hukum Islam. Jurnal Hukum Diktum. Vol.11, No.2.

[26] Suradinata, Ermaya. 2015. Reformasi Organisasi dan Administrasi Pemerintahan. Jakarta: Lembaga Ketahanan Nasional Republik Indonesia.

[27] Olivia, Tindas. Tanpa Tahun. Perilaku Birokrasi Pelayanan Izin Mendirikan Bangunan di Kota Tomohon. www.google scolar. (Diakses tanggal 25 Desember 2020).

[28] Uma, Sekaran. 2006. Research Methods For Business Metode Penelitian untuk Bisnis. Bandung: PT. Salemba Empat.

[29] Undang-undang Nomor 5 Tahun 2014 tentang Aparatur Sipil Negara

[30] Wahjusaputri, Sintha dan Irawan, Bambang. 2019. Bureaucratic Reform Policy Strategy Using The Cipp Model For The Improvement Of Public Services In Kemenko-Polhukam. Jurnal Universitas Muhammadiyah Prof. Dr. Hamka. Vol.3, No.1.

[31] Walgito, Bimo. 2002. Pengantar Psikologi Umum. Yogyakarta: Andi Offset.

[32] Yusuf, Muri. 2019. Metode Penelitian Kuantitatif, Kualitatif, dan Penelitian Gabungan. Jakarta: Prenadamedia Group.

[33] Zainal Arifin. 2005. Penelitian Pendidikan Metode danParadigma Baru. Bandung: Remaja Rosdakarya. 